\title{
Target metabolite and gene transcription profiling during the development of superficial scald in apple (Malus $x$ domestica Borkh)
}

\author{
Nicola Busatto ${ }^{1}$, Brian Farneti ${ }^{1}$, Alice Tadiello², Urska Vrhovsek ${ }^{2}$, Luca Cappellin², Franco Biasiolii ${ }^{2}$, Riccardo Velasco ${ }^{2}$,
} Guglielmo Costa ${ }^{1}$ and Fabrizio Costa ${ }^{2^{*}}$

\begin{abstract}
Background: Fruit quality features resulting from ripening processes need to be preserved throughout storage for economical reasons. However, during this period several physiological disorders can occur, of which superficial scald is one of the most important, due to the development of large brown areas on the fruit skin surface.

Results: This study examined the variation in polyphenolic content with the progress of superficial scald in apple, also with respect to 1-MCP, an ethylene competitor interacting with the hormone receptors and known to interfere with this etiology. The change in the accumulation of these metabolites was further correlated with the gene set involved in this pathway, together with two specific VOCs (Volatile Organic Compounds), a-farnesene and its oxidative form, 6-methyl-5-hepten-2-one. Metabolite profiling and qRT-PCR assay showed these volatiles are more heavily involved in the signalling system, while the browning coloration would seem to be due more to a specific accumulation of chlorogenic acid (as a consequence of the activation of $M d P A L$ and $M d C(H H$ ), and its further oxidation carried out by a polyphenol oxidase gene (MdPPO). In this physiological scenario, new evidence regarding the involvement of an anti-apoptotic regulatory mechanism for the compartmentation of this phenomenon in the skin alone was also hypothesized, as suggested by the expression profile of the MdDAD1, MdDND1 and MdLSD1 genes.
\end{abstract}

Conclusions: The results presented in this work represent a step forward in understanding the physiological mechanisms of superficial scald in apple, shedding light on the regulation of the specific physiological cascade.

Keywords: Malus domestica, Cold storage, Postharvest, Superficial scald, 1-MCP, Polyphenol oxidase, Polyphenols, a-farnesene, Programmed death cell

\section{Background}

Fruit quality is determined by a series of physiological modifications taking place throughout the maturation and ripening of fruit, starting from the initial phase of fruit development. These processes, which concern modification of the cell wall structure, accumulation in pigments, conversion of starch into sugar, the decrease in organic acid and flavour formation, are genetically coordinated in order to render the fruit more palatable to seed-dispersing organisms as well as more attractive for human consumption and diet [1-3]). Fruit ripening behaviour can also be

\footnotetext{
* Correspondence: fabrizio.costa@fmach.it

${ }^{2}$ Research and Innovation Centre, Fondazione Edmund Mach, Via Mach 1, 38010 San Michele all'Adige, Trento, Italy

Full list of author information is available at the end of the article
}

divided into two classes (climacteric and non climacteric), according to the level of ethylene, a plant hormone fundamental for triggering and coordinating the processes leading to the final quality of fruit $[4,5]$. To guarantee the maintenance of high quality standard, fruits are to date stored for a long time in an altered atmosphere, with the application of conditions such as low temperature or low oxygen concentration. These are non-physiological conditions interfering with physiological ethylene production and consequently with the natural progression of fruit ripening and senescence [6-8]. During postharvest storage, however, many disorders related to abiotic stress may arise due to chilling injuries or hypoxia [9-14].

Of the several postharvest disorders that can occur, superficial scald is one of the most important. In apple, 
the predominant scald symptom is represented by diffuse browning, generally limited to the skin and the underlying six cell layer [15]. This disorder normally occurs after the re-establishment of room temperature $\left(20^{\circ} \mathrm{C}\right)$ following two or more months of cold storage (at -1 to $4^{\circ} \mathrm{C}$; [16]). Superficial scald is a complex phenomenon influenced by environmental and genetic factors as well as the stage of fruit ripening. Specific apple cultivars, such as "Granny Smith", "Fuji", "Cripps Pink" and "Red Delicious" are, indeed, more susceptible than others [17]. Furthermore, ripe fruit is less susceptible to scald then immature fruit [18], and the green side of an apple is generally more prone to developing scald symptoms than the red one [19]. Despite the harmfulness and diffusion of this disorder, its etiology has still not been fully elucidated [20]. To date, the most investigated and accepted hypothesis about scald development is related to the accumulation of $\alpha$-farnesene, an acyl sesquiterpene whose concentration increases during storage. This volatile is accumulated significantly in the skin, in particular in the external wax layer, due to its lipophilic characteristics [19,21,22]. Recent works have correlated the induction of superficial scald with the accumulation of $\alpha$-farnesene autoxidation products, such as conjugated trienols (CTols), mainly 2,6,10-trimethyldodeca2,7E,9,11-tetraen-6-ol [23]. The synthesis of $\alpha$-farnesene is also supposed to be closely linked to the amount of ethylene [24], since this hormone modulates the expression of MdAFS1 ( $\alpha$-farnesene synthase 1$)$, the last gene in the $\alpha$-farnesene biosynthetic pathway. The close connection between ethylene and $\alpha$-farnesene was also further confirmed by the effect of the ethylene competitor 1-methylcyclopropene (1-MCP), which leads to a reduced accumulation of $\alpha$-farnesene. $1-\mathrm{MCP}$ is known to strongly influence the normal fruit ripening progression in climacteric fruit, due to its competing effect against ethylene at receptor level [25], as already documented in several genomic investigations carried out on apple, tomato and peach [26-31]. Beside this, 1-MCP has been recently also been widely used for the control of superficial scald in apple [32]. The complete mode of action of this compound in preventing scald is not yet fully clear, despite the fact that samples treated with 1-MCP showed a decreased expression of MdAFS1 [19,33-35]. Other recent references have instead indicated the initiation of free radical oxidation as the main factor of scald development in apple [36]. In this scenario, the autoxidation of $\alpha$-farnesene could represent a side effect of a more complex and uncompleted process. In addition to the role of $\alpha$-farnesene, there is another hypothesis about the oxidation of polyphenolic compounds, considered to be fundamental in generating of the browning of skin. These compounds, after the disruption of the cell inner membranes, interact with the polyphenol-oxidase enzyme (PPO) released from the chloroplast [37]. PPO thus turns polyphenols into oxidized forms, such as quinones [38-40]. Amines and thiol groups react with quinones, ultimately leading to the formation of brown pigments. This reduction has already been proposed by Boss et al. [41], who observed an upregulation of polyphenol oxidase transcripts in "Granny Smith" scalded tissues, while Piretti et al. [42] hypothesized that the brown pigmentation exhibited during scald was the final result of an oligomeric polyphenolic oxidation.

The effort of the scientific community to gain insight into superficial scald in apple, besides the understanding the basic physiological mechanisms governing this phenomenon, have mainly been focused on strategies designed to avoid this disorder [43-45]. Scalded fruit indeed has dramatic aesthetic deficiencies that can seriously compromise fruit marketability. To deal with this problem, several technological applications have been employed, such as forced ventilation, skin coating, heat shock and chemical treatment, in particular with DPA (diphenylamine [46]). However, while this amino antioxidant has been widely used untill now [47], its application is currently undergoing serious review, due to the possible risks associated with the compound. As an alternative molecule, postharvest management has taken advantage of 1-MCP, an ethylene inhibitor widely adopted to extend the storage capacity of climacteric fleshy fruits $[48,49]$. However, most of the works presented so far in the scientific literature have been based mainly on enzymatic assay and the expression profile of a limited set of genes involved in this phenomenon, such as AFS and PPO.

In this work the change in the polyphenolic cascade was examined during the development of apple scald using a candidate gene qRT-PCR approach, together with targeted metabolic profiling. Finally, specific expression profiling based on different tissues suggested an intriguing evidence about the involvement of the programmed cell death (PCD) process, as a possible natural defence mechanism put into effect by the fruit to prevent the expansion of this postharvest disorder in apple. The results described and discussed in this work shed light on specific aspects of this disorder, helping to better clarify the physiological mechanisms taking place after harvest in apple fruit.

\section{Methods}

\section{Plant materials and experimental design}

Fruit were collected from "Granny Smith" apple trees planted in Faenza (Emilia-Romagna region, Italy), and maintained following standard agronomical practices in terms of mineral fertilisation, fruit thinning, canopy pruning and disease control. Apples were picked at the commercial harvest stage, instrumentally established at the $\mathrm{I}_{\mathrm{AD}}$ value of 1.8-2. The $\mathrm{I}_{\mathrm{AD}}$ is a non-destructive index of fruit ripening determined as the difference in 
absorbance between two wavelengths near the chlorophylla absorption peak (670 and $720 \mathrm{~nm}$; [50,51]). Homogeneous fruit (in terms of both ripening stage and shape) were sampled immediately after harvest (T0), and immediately divided into two batches. The first was treated with 1 ppm of 1-methyl-cyclopropene (1-MCP) for 24 hours, while the second was maintained as a control. The two sample batches were stored in cold room in normal atmospheric conditions at $0.5^{\circ} \mathrm{C}$ with $95 \%$ relative humidity. Samples from the two batches, were then removed from the cold room after one month (T1) and two months (T2) cold storage respectively. To further enhance scald development, additional apples were sampled three times during each period of cold storage, respectively after one $(+1)$, four $(+4)$ and eight $(+8)$ days shelf life (room temperature of about $20^{\circ} \mathrm{C}$; Additional file 1: Figure S1). To investigate symptom development throughout the fruit cortex, three types of tissues were assessed for each sample: skin ( $\mathrm{S}$, the peel and the underlying affected flesh), underskin (U, the few millimetres of flesh below the skin) and inner pulp (P).

\section{RNA isolation and qRT-PCR analysis}

For each fruit, three tissues (skin, underskin flesh and pulp) were separately collected, cut in small pieces, immediately frozen in liquid nitrogen, ground into a fine powder and stored at $-80^{\circ} \mathrm{C}$ until final processing. RNA extraction was performed using the Spectrum Plant total RNA kit (Sigma-Aldrich Co., St Luis, MO, USA). RNA was quantified using a NanoDrop ND-8000 spectrophotometer (Thermo Scientific, Waltham, MA, USA), while its purity and integrity was assessed with a 2100 Bioanalyzer (Agilent, Santa Clara, CA, USA). The RNA isolated was then converted into cDNA using the "SuperScript VILO cDNA Synthesis Kit" (Life Technologies, Carlsbad, CA, USA). Prior to this, $2 \mu \mathrm{g}$ of total RNA from each sample was treated with 2 Units of Ambion rDNAse I (DNA free kit, Life Technologies, Carlsbad, CA, USA) and used as a starting template. Transcript quantification, carried out using the ViiA $7^{\mathrm{TM}}$ instrument (Life Technologies, Carlsbad, CA, USA), was performed using the FAST SYBR GREEN MASTER MIX (Life Technologies, Carlsbad, CA, USA). PCR thermal conditions were: incubation at $95^{\circ} \mathrm{C}$ for $20 \mathrm{sec}, 40$ cycles of $95^{\circ} \mathrm{C} 1 \mathrm{sec}$ and $60^{\circ} \mathrm{C} 20 \mathrm{sec}$. Finally, a cycle at $95^{\circ} \mathrm{C}$ for $15 \mathrm{sec}, 60^{\circ} \mathrm{C}$ for $1 \mathrm{~min}$ and $95^{\circ} \mathrm{C}$ for $15 \mathrm{sec}$ was applied to determine the melting curve. The $\mathrm{Ct}$ results were obtained by averaging two independent normalized expression values for each sample, carried out using the $\mathrm{ViiA}^{\mathrm{sm}} 7$ Software (Life Technologies, Carlsbad, CA, USA) provided with the instrument. Relative gene expression was plotted as the mean of the normalized expression values using the Delta-Delta CT method [52] and Md8283 was employed as housekeeping gene [53,54].

\section{Gene identification and primer design}

The gene set investigated in this survey was selected on the basis of the polypohenolic pathway as described by Kirk et al. [55]. Since a strong correlation has already been observed between the metabolism of polyphenolic compounds and a similar phenotype in apple (flesh browning [40]), we focused our efforts on comprehension of polyphenolic pathway regulation. The gene ID was retrieved from studies already published [56-62] for each member responsible for this physiological biosynthetic pathway, while cDNA sequences were in silico retrieved from the NCBI database (http://www.ncbi.nlm.nih.gov/). The ORF portion was defined from each sequence, in order to characterize the CDS from the UTR portions, when possible. To target the corresponding specific apple element, each single CDS sequence was blasted on the apple geneset available in the Rosaceae database (www. rosaceae.org). Gene IDs with the highest E-value and score were selected as candidates. For each gene, specific primer pairs were designed on the flanking regions of each MDP, isolated by aligning the UTR on the cDNA sequence, in order to define unique target elements for each polyphenolic biosynthetic gene. In addition to these, the expression profile of other five genes was assessed. The polyphenol oxidase gene MdPPO (MDP0000699845) was retrieved by Di Guardo et al. [40], while MdAFS1, involved in the biosynthetic pathway of $\alpha$-farnesene, was selected by blasting the cDNA sequence designed in Lurie et al. [33] on the apple genome following the procedure previously described. Finally, three genes (MdDAD1, MdDND1 and MdLSD1) involved in antiapoptosis mechanism were also considered. The cDNA sequence of $M d D A D 1$ was obtained from Dong et al. [63] and used a BLAST query in order to identify the corresponding MDP in the geneset mentioned above. DND1 [64] and LSD1 [65] were selected as candidate antiapoptotic genes due to the function previously characterized in Arabidopsis thaliana. The cDNA sequences of these elements were initially retrieved from the Arabidopsis database (www.arabidopsis.org), and further blasted on the apple geneset (Additional file 2: Figure S2). Gene predictions with the highest E-value and score were chosen as candidate homologues in apple.

\section{Polyphenolic compound extraction and separation}

Phenols were extracted and analysed from the ground tissues of "Granny Smith" apples following the procedure reported in Theodoridis et al. [66] and Di Guardo et al. [40]. Each sample was represented by three biological replicates. $2 \mathrm{~g}$ of powdered tissues were extracted in sealed glass vials using $4 \mathrm{~mL}$ of water/methanol/chloroform solution (20:40:40). After vortexing for $1 \mathrm{~min}$, the samples were mixed using an orbital shaker for $15 \mathrm{~min}$ at room 
temperature, and further centrifuged at $1000 \mathrm{~g}\left(4^{\circ} \mathrm{C}\right)$ for $10 \mathrm{~min}$, after which the upper phases, made up of aqueous methanol extract, were collected. Extraction was repeated by adding another $2.4 \mathrm{~mL}$ of water/methanol (1:2) to the pellet and chloroform fractions. After the final centrifugation, the upper phases from the two extractions were combined and brought to the volume of $10 \mathrm{~mL}$ and filtered with a $0.2 \mu \mathrm{m}$ PTFE filter prior to liquid chromatographymass spectrometry analysis. Ultraperformance liquid chromatography was performed employing a Waters Acquity UPLC system (Milford, MA, USA) coupled to a Waters Xevo TQMS (Milford, MA, USA) working in ESI ionisation mode [67]. Separation of the phenolic compounds was achieved on a Waters Acquity HSS T3 column $1.8 \mu \mathrm{m}, 100 \mathrm{~mm} \times 2.1 \mathrm{~mm}$ (Milford, MA, USA), kept at $40^{\circ} \mathrm{C}$, with two solvents: A (water containing $0.1 \%$ formic acid) and $\mathrm{B}$ (acetonitrile containing $0.1 \%$ formic acid). The flow was $0.4 \mathrm{~mL} / \mathrm{min}$, and the gradient profile was $0 \mathrm{~min}$, $5 \% \mathrm{~B}$; from 0 to $3 \mathrm{~min}$, linear gradient to $20 \% \mathrm{~B}$; from 3 to $4.3 \mathrm{~min}$, isocratic $20 \% \mathrm{~B}$; from 4.3 to $9 \mathrm{~min}$, linear gradient to $45 \% \mathrm{~B}$; from 9 to $11 \mathrm{~min}$, linear gradient to $100 \% \mathrm{~B}$; from 11 to $13 \mathrm{~min}$, wash at $100 \% \mathrm{~B}$; from 13.01 to $15 \mathrm{~min}$, back to the initial conditions of $5 \%$ B. A volume of $2 \mu \mathrm{L}$ from both standard solutions and samples was injected, after which the needle was rinsed with $600 \mu \mathrm{L}$ of weak wash solution (water/methanol, 90:10) and $200 \mu \mathrm{L}$ of strong wash solution (methanol/water, 90:10). Samples were kept at $6^{\circ} \mathrm{C}$ during mass spectrometry detection, performed with a Waters Xevo TQMS (Milford, MA, USA) instrument equipped with an electrospray (ESI) source. Capillary voltage was $3.5 \mathrm{kV}$ in positive mode and $-2.5 \mathrm{kV}$ in negative mode; the source was kept at $150^{\circ} \mathrm{C}$; desolvation temperature was $500^{\circ} \mathrm{C}$; cone gas flow, $50 \mathrm{~L} / \mathrm{h}$; and desolvation gas flow, $800 \mathrm{~L} / \mathrm{h}$. Unit resolution was applied to each quadrupole. Data were processed using Waters MassLynx 4.1 and TargetLynx software.

135 phenolic compounds were initially selected for the quantitative measurement assay [67]. The choice of the metabolites was mainly based on their importance and/ or relevance for food quality, covering the major classes. In particular, benzoates, phenylpropanoids, coumarins, stilbenes, dihydrochalcones, and flavonoids commonly occurring in plants were included, together with metabolites specific to a single species or family. Stock solutions of each individual standard solution were prepared in pure methanol. These starting solutions were used to prepare 16 standard mixtures including $6-10$ compounds each. Serial dilutions were prepared to obtain 24 lower concentrations (dilution factors of $1-60000$ ) for linear dynamic range assessment.

\section{VOC characterization using PTR-ToF-MS}

Measurements of VOCs in apple tissues were performed as follows. $2.5 \mathrm{~g}$ of powdered frozen tissue were immediately inserted into a $20 \mathrm{~mL}$ glass vial equipped with PTFE/silicone septa (Agilent, Santa Clara, CA, USA) and mixed with $2.5 \mathrm{~mL}$ of deionized water, $1 \mathrm{~g}$ of sodium chloride, $12.5 \mathrm{mg}$ of ascorbic acid, and $12.5 \mathrm{mg}$ of citric acid, and then preserved at $4^{\circ} \mathrm{C}$ untill the assessment. Analysis was performed on three replicates using commercial PTRToF-MS 8000 apparatus (Ionicon Analytik GmbH, Innsbruck, Austria). The conditions in the drift tube were: $110^{\circ} \mathrm{C}$ drift tube temperature, $2.25 \mathrm{mbar}$ drift pressure, $550 \mathrm{~V}$ drift voltage. This leads to an $\mathrm{E} / \mathrm{N}$ ratio of about 140 Townsend (Td), with E corresponding to the electric field strength and $\mathrm{N}$ to the gas number density $(1 \mathrm{Td}=10$ $17 \mathrm{Vcm} 2$ ). The sampling time per channel of ToF acquisition was $0.1 \mathrm{~ns}$, amounting to 350,000 channels for a mass spectrum ranging up to $\mathrm{m} / \mathrm{z}=400$. Each measurement was conducted automatically after 20 minutes of sample incubation at $40^{\circ} \mathrm{C}$ by using an adapted GC autosampler (MPS Multipurpose Sampler, GERSTEL) and it lasted for about 2 minutes. During measurements $100 \mathrm{sccm}$ of zero air was continuously injected into the vial, through a needle heated to $40^{\circ} \mathrm{C}$; the outflow was instead delivered via Teflon fittings to the PTR-Tof-MS through a second heated needle $\left(40^{\circ} \mathrm{C}\right)$. The analysis of PTR-ToF-MS spectral data proceeded as follows. Count losses due to the ion detector dead time were corrected off-line through a Poisson statistics based method [68], while internal calibration was performed according to the procedure described in Cappellin et al. [69]. This approach makes it possible to reach a mass accuracy higher than $0.001 \mathrm{Th}$, which is sufficient for sum formula determination in our case. Compound annotation was carried out following comparison of spectra with the fragmentation data of compound reference standards. Noise reduction, baseline removal and peak intensity extraction were performed by using modified Gaussians to fit the peaks. Absolute headspace VOC concentrations expressed in ppbv (parts per billion by volume) were calculated from peak intensities according to the formula described by Lindinger et al. [70]. A constant reaction rate coefficient of $2 \cdot 10-9 \mathrm{~cm} 3 / \mathrm{s}$ was used in the calculations, introducing a systematic error of up to $30 \%$ that can account for the actual rate if the coefficient is known [71].

\section{Results and discussion}

\section{Superficial scald development in "Granny Smith" and the polyphenolic pathway}

To study the accumulation and progression of superficial scald development, fruit from the "Granny Smith" apple cultivar were divided in two groups immediately after harvest, one group being kept as a control while the second was treated with 1-MCP, an ethylene competitor [72] known to interact with scald development in apple [73]. The physiological progression of the disorder was monitored by sampling apples at two storage periods (one and 
two months respectively), as well as three times during eight days shelf life, as shown in Additional file 1: Figure S1. Following visual inspection, browning in scalded apples occurred only in the skin of T2 stage control samples, with an increasing magnitude over the week of shelf life (Additional file 3: Figure S3). For each sample included in this experimental design, three tissues were specifically isolated, skin, underskin, and inner flesh (pulp), in order to verify the spatial response of the fruit to this phenomenon, in terms of gene expression and secondary metabolite variation. The pathway investigated here considered the biochemical cascade of phenylamine, which leads to the synthesis of polyphenols, such as chlorogenic acid, flavonols, flavan-3-ols (catechin and epicatechin), as illustrated in Figure 1. Expression of 11 structural genes (Additional file 4: Table S1) was located and analyzed along this pathway. Of these six (MdPAL, MdCHS, MdCHI, MdF3H, MdDFR and MdANS) were designated to the main central cascade. Furthermore, $M d C 3 H, M d F L S, M d L A R$ and $M d A N R$ were selected because of their essential role in the formation of four distinct major classes of polyphenolic compounds: chlorogenic acids, flavonols, epicatechin and catechin, respectively. Moreover, one member of the PPO family was also

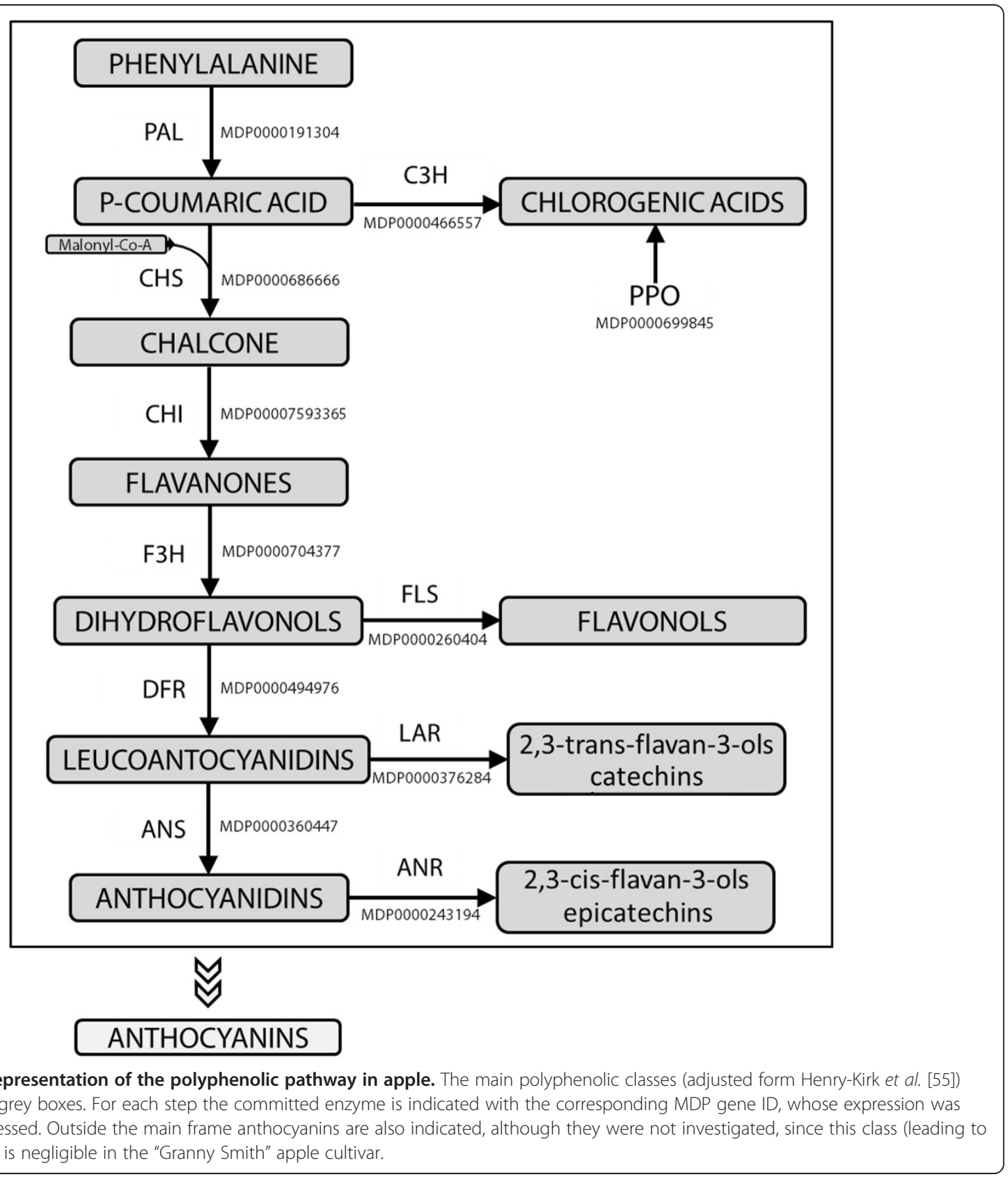


investigated (MDP0000699845) as responsible for the transformation of polyphenolic compounds into oxidized brownish forms.

\section{The candidate gene expression profile and polyphenol quantification showed chlorogenic acid is the major determinant in superficial scald development}

The polyphenol content was quantified for all the samples, characterizing five major compounds namely chlorogenic acid, phlorizin, flavonols, catechin and epicatechin. In a general overview, the total polyphenolic accumulation (Additional file 5: Figure S4 and Additional file 6: Table S2) was clearly higher in the skin as compared to the other two tissues (underskin and pulp) with about a 5 fold of change. This trend is also confirmed by the different accumulation of phlorizin, flavonols and epicatechin, but not catechin. According to previous studies [74-76] "Granny Smith" fruit often showed a lower concentration of catechin than epicathechin, especially in the skin, where the amount of epicatechin is approximately double.
Examining each category, a specific regulation over the period of storage was also observed. In phlorizin, for instance, the accumulation in the samples collected after two months of storage (T2) was lower than after one month (T1), while for flavonols an opposite trend was detected (Additional file 5: Figure S4). In addition to this, for some compounds (such as phlorizin, assessed in underskin and pulp collected at T1, and flavonol at T1 and $\mathrm{T} 2_{\mathrm{S}+1}$ in skin and underskin) a reduced accumulation was also detected after treatment with 1-MCP. This general polyphenolic accumulation (Figure 2B) was compared with the transcript profile of the eleven genes selected to represent the biosynthetic pathway of these metabolites (Figure 2A). From the general heatmap, illustrating both the expression profile and the polyphenolic accumulation in the skin alone (tissue concerned by superficial scald), it is worth noting the different transcriptomic pictures in the control and treated samples. This particular response after treatment highlighted how 1MCP is used to turn off fundamental genes involved in

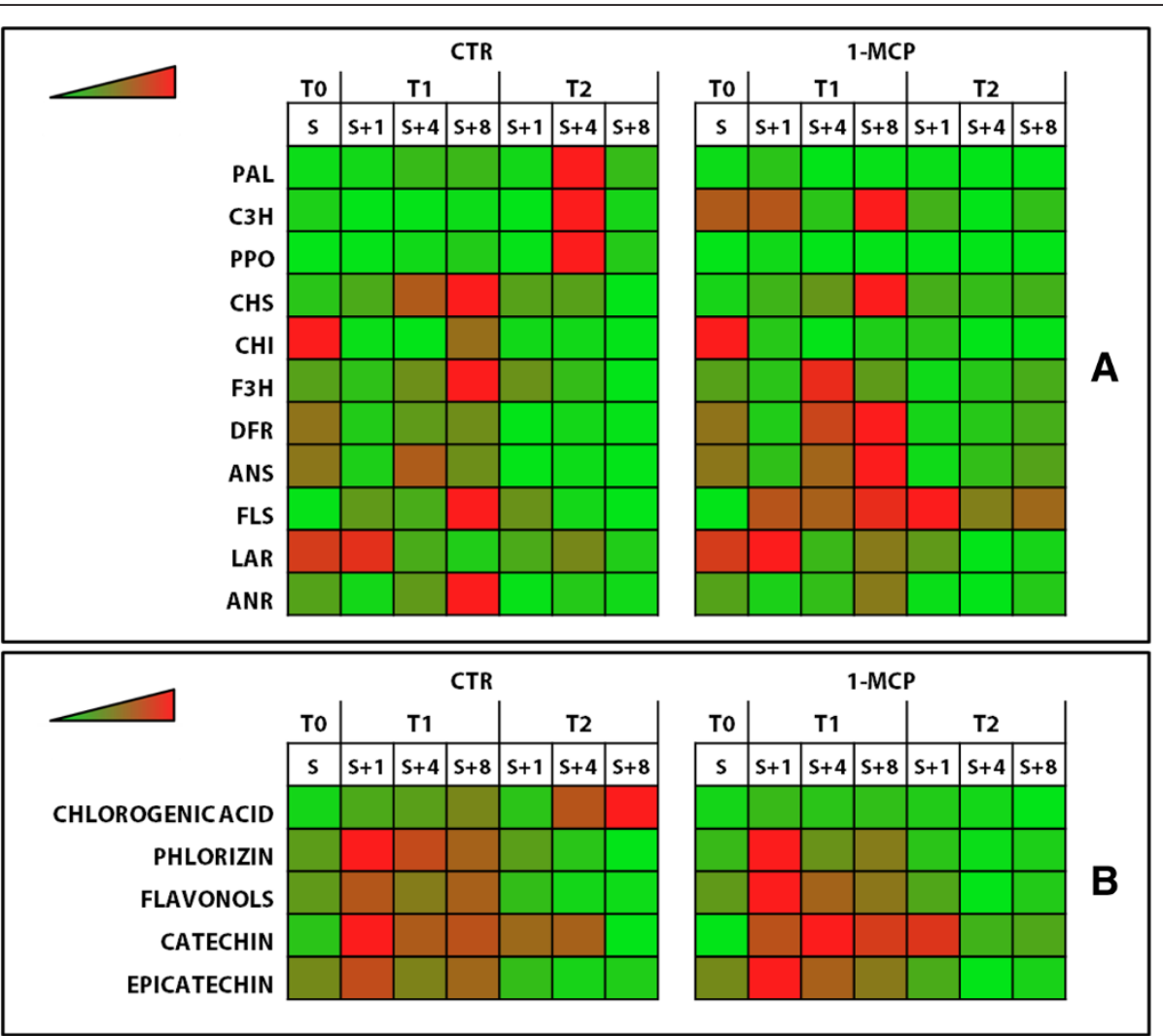

Figure 2 Gene expression and secondary metabolite heat-map profile in skin tissue. Gene transcript dynamics are shown in panel A, while panel B shown the accumulation of secondary metabolites in the control (CTR, showing scald) and 1-MCP treated sample (in which this disorder was prevented). For both panels, data spanned from light green (low intensity) to light red (high intensity), as illustrated by the color scale. The data plotted on panel "A" are expressed as normalized expressions, whereas panel "B" shows $\mu \mathrm{g} / \mathrm{g}$ of fresh weight (FW). The full gene expression and metabolite profile for the entire set of tissues are shown in Figures 3 and 5 as well as in Additional file 5: Figure S4 and Additional file 6: Table S2. 
the ripening pathway, modifying gene expression and detecting three main transcriptome dynamics. In the first group three genes, $M d P A L, M d P P O$ and $M d C 3 H$, specifically expressed at the $\mathrm{T} 2_{\mathrm{S}+4}$ stage (coinciding with scald development), were completely down-regulated by 1 -MCP, suggesting possible positive regulation by ethylene. In the specific case of the last gene, $M d C 3 H$, designated to controlling the final synthesis of the chlorogenic acid, the application of 1-MCP slightly anticipated its mRNA accumulation from the T2 to the T1 stages. The second group, represented by the three genes ( $M d C H S, M d C H I$ and $M d F 3 H$ ) involved in the cascade from $p$-coumaric acid to dihydroflavonols (step before the branching to flavonols), together with $M d A N R$ (involved in the final conversion of flavan-3-ols from anthocyanidins), showed a reduction in transcript accumulation after the application of the ethylene competitor 1-MCP. Finally the expression level of the last set of genes $(M d D F R$, $M d A N S, M d F L S$ and $M d L A R)$, located downstream of the polyphenolic pathway, was instead slightly enhanced by the application of 1-MCP (Figure 2 and Additional file 7: Figure S5).

Although superficial scald is a phenomenon which mainly concerns fruit skin, further investigation of the possible progression in inner tissue was assessed. In particular, we aimed to unravel the response mechanism limiting browning progression. The different categories of polyphenolic compounds were differently accumulated in the samples defined in the experimental design planned here. In particular, phlorizin, catechin and epicatechin decreased constantly throughout storage and shelf life, while flavonols showed contrasting dynamics, as they were instead accumulated (Additional file 5: Figure S4). The most interesting profile was observed for the chlorogenic acid, which was accumulated in the skin tissue from T1 to T2 (as well as over the shelf life progression), while in underskin and pulp tissues it showed a decreasing trend during the different stages. The higher accumulation of chlorogenic acid (Figure 3A) coincided with the scald burst occurring in the $\mathrm{T} 2_{\mathrm{S}+4}$ stage, which was also characterized by the highest expression level of the genes involved in the chlorogenic acid pathway, namely $M d P A L, M d C 3 H$ and $M d P P O$ (Figure 3B, $\mathrm{C}$ and $\mathrm{D})$. The increased production of chlorogenic acid during scald, accompanied by the activation of $P A L$ and $\mathrm{C} 3 \mathrm{H}$, can be though to be an antioxidant protection system activated by the fruit during storage. The appearance of superficial scald in "Granny Smith" apples is indeed often positively correlated with the accumulation of reactive oxygen species in the damaged tissues $[36,77]$, probably caused by the negative effect of cold storage on the fluidity and integrity of cell membranes [78], leading to ion leakage and to general decompartmentation. This phenomenon related to chilling injuries, has been observed for apple, as well as for other fruit species $[10,79]$.

In this scenario, browning coloration may occur as a response to the activation of $M d P P O$ (which uses chlorogenic acid as the main substrate), to maintain the system in a state of physiological equilibrium, as also observed in the case of internal browning [40], a similar process resulting in the induction of $M d P A L$ and $M d P P O$. In contrast to internal browning, superficial scald was more localized in the cell of the skin layer. This tissue specificity, already highlighted by the polyphenolic analysis, is also supported by specific gene expression. $M d P A L, \mathrm{MdC} 3 \mathrm{H}$ and $M d P P O$ are indeed mainly expressed in the skin rather than in the underskin and pulp, as compared to the other genes involved in the polyphenolic pathway (Figure 3 and Additional file 7: Figure S5). The specific accumulation of both chlorogenic acid and relative gene transcripts suggest that this compound and subsequent activation of $M d P P O$ gene are the main events in the development of the disorder. This hypothesis is also experimentally supported by comparison with the samples treated with 1-MCP. This compound, known to interfere with scald development during postharvest storage [80], effectively blocked the synthesis of chlorogenic acid in the skin (Figure 3A). In parallel, 1-MCP strongly and specifically downregulated the expression of $M d P A L, M d C 3 H$ and $M d P P O$ (Figure 3B, C and D). The fact that the application of the ethylene competitor was not equally effective in the other genes located in the polyphenolic pathway (Additional file 7: Figure S5) supported the role of chlorogenic acid as the fundamental physiological pathway concerned during browning. It is also interesting to note that the effect of 1-MCP, particularly in the T2 stages (affected by the incidence of skin browning), was less evident in the inner tissues (underskin and pulp). The expression level of $M d C 3 H$ was basically unchanged in the underskin and pulp tissues (Figure $3 \mathrm{C}$ ), suggesting that scald in apple focuses on the skin because of specific metabolic regulation of these classes of secondary metabolites in different fruit tissues, in response to localized chilling injury. It is also worth noting two inconsistencies observed between gene expression level and metabolite accumulation. The first was represented by the peak in expression of $M d P A L$ at $\mathrm{T} 2_{\mathrm{U}_{+} 4}$, which does not correlate with the unchanged accumulation of chlorogenic acid. This trend can however be explained by the low expression of $M d C 3 H$, suggesting the incomplete biosynthesis of chlorogenic acid, this gene representing this gene the final step in this cascade. Another incongruence regarded the high accumulation of this compound in the pulp, despite a low gene activity in the T1 stages. This situation can be explained by an accumulation of chlorogenic acid during the first month of 


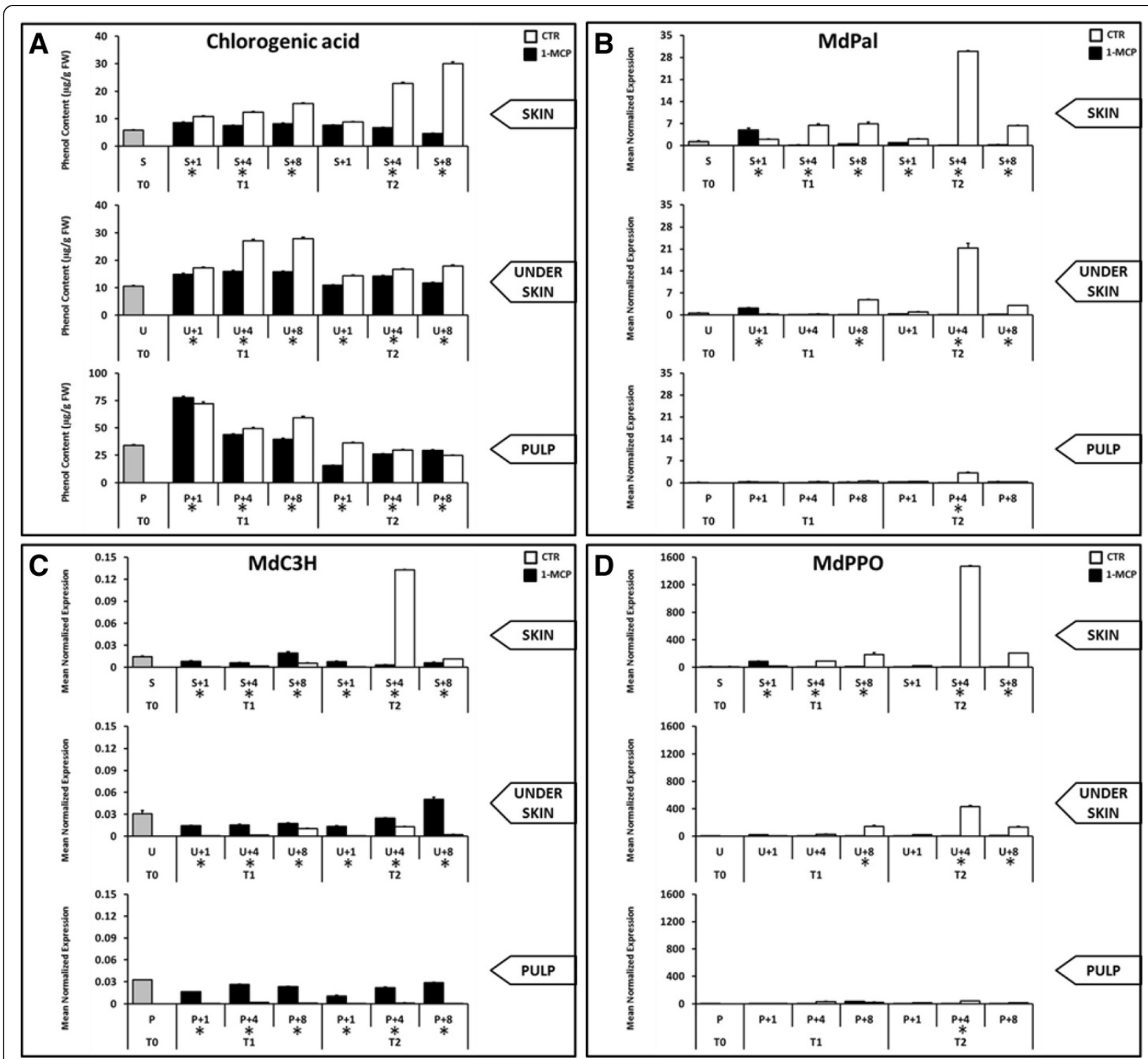

Figure 3 Physiological regulation of the chlorogenic acid over time and in tissues and treatments. Panel " $A$ " shows the accumulation of this secondary metabolite in $\mu \mathrm{g} / \mathrm{g}$ of FW. The other three panels (B, $\mathbf{C}$ and $\mathbf{D}$ ) instead illustrate the expression profile of the three genes involved in the chlorogenic acid pathway, namely MdPAL, MdC3H and MdPPO, and its oxidation process. Gene expression is visualized on the basis of Mean Normalized Expression. The bar on the histogram represents the standard error for each panel. Asterisk indicates a difference statistically significant based on a LSD-ANOVA ( $P$-value $\leq 0.05)$.

cold storage, after which it showed continuous and linear degradation, thus not requiring the activation of this biosynthetic pathway for the synthesis of new chlorogenic acid.

The role of a-farnesene and CTols during scald development in apple

In addition to the polyphenolic characterization, further investigation of the role of $\alpha$-farnesene and its oxidative product $6 \mathrm{M} 5 \mathrm{H} 2$ one (6-methyl-5-hepten-2-one) was also carried out. $\alpha$-farnesene has been indicated to date as the main compound involved in scald development [81]. In particular, it is the oxidative products of $\alpha$-farnesene that have been suggested to be the causal agent of this disorder, since external application of CTols on the skin of "Granny Smith" apples induced the development of scald-like symptoms [23]. To verify the role of $\alpha$-farnesene and $6 \mathrm{M} 5 \mathrm{H} 2$ one in the process, these two volatile organic compounds (VOCs) were measured using a PTR-ToFMS, the new version of a mass spectrometer based on a proton transfer reaction [82]. 
According to other references $[16,19,20,33] \alpha$-farnesene was linearly accumulated after the first month of cold storage and in particular during the first period of room temperature shelf life, with a clear increase from the $\mathrm{T} 1_{+1}$ to $\mathrm{T} 1_{+8}$ stages, after which a more constant profile was observed during T2 shelf life (Figure 4B). The burst in this volatile was positively correlated with the activation and transcription dynamics of MdAFS1, the gene designated to encoding the last step of the $\alpha$-farnesene synthesis (Figure 4A). MdAFS1 increased its mRNA level from $\mathrm{T} 1_{\mathrm{S}+1}$ to $\mathrm{T} 1_{\mathrm{S}+8}$, to then decrease in the $\mathrm{T} 2$ stages. Volatile concentration and MdAFS1 expression were significantly affected by $1-\mathrm{MCP}$, since its application reduced both VOCs and MdAFS1 accumulation almost completely (Figure 4A, C and B). Beside $\alpha$-farnesene, PTR-ToF-MS also efficiently detected $6 \mathrm{M} 5 \mathrm{H} 2$ one, a volatile ketone produced through oxidation of $\alpha$-farnesene. Rowan et al. [23] suggested that the concentration of $6 \mathrm{M} 5 \mathrm{H} 2$ one resulting from autoxidation of $\alpha$-farnesene, could be considered to be a reliable indicator of oxidation in apple peel, since the autoxidation of $\alpha$-farnesene indicates a free-radical-mediated reaction, involved in the production of CTols [20,83].

Interestingly, the accumulation of 6M5H2one occurred after its precursor. 6M5H2one, indeed remained at basal concentration as compared to harvest, throughout the T1 stages, after which its accumulation increased considerably during the T2 stages (Figure $4 \mathrm{C}$ ), coinciding with the development of scald symptoms. The time-wise regulation of these two VOCs suggests that rather than being the causal event of scald, $\alpha$-farnesene and $6 \mathrm{M} 5 \mathrm{H} 2$ one play a more regulatory role. In this scenario, we can surmise that $\alpha$-farnesene is accumulated in apple skin during postharvest storage. Then, in response to oxidative stress (one of the possible cause stimulating the development of scald) the $\alpha$-farnesene may be auto-oxidized in CTols, which then act as a signaling molecule, triggering a defence mechanism based on antioxidant protection, carried out by an increased accumulation of polyphenolic compounds, in particular chlorogenic acid. To maintain the system with feedback regulation, the excess of chlorogenic acid is then oxidized by the polyphenolic oxidase enzyme, generating the consequent brown coloration.

\section{An anti-apoptosis system can activate a defence mechan- ism against scald progression in apple}

In addition to the genes involved in the polyphenolic cascade, three elements involved in the apoptosis mechanism were also investigated, namely $M d D A D 1, M d D N D 1$ and MdLSD1.

The involvement of programmed cell death (PCD) activity in the progress of post-harvest disorders in apple has recently been suggested [84], hypothesizing a possible role for PCD, in synergy with oxidative stress and ethylene, as part of a series of processes leading to superficial scald, internal browning and bitter pit symptoms. To the best of our knowledge, very little data about PCD in apple have been presented till now, and in most cases they were related to stress responses in the suspension of cell cultures $[85,86]$. To date, the only clear evidence about the presence of the PCD mechanism during apple storage is represented by the activity of $D A D 1$. As reported by Dong et al. [63], $M d D A D 1$ is an apple element encoding for a subunit of the mammalian oligosaccharyltransferase homolog (defender against cell death 1 - DAD1), whose expression gradually rises during ripening at room temperature. DND1 in Arabidopsis (AT5G15410) instead encodes a functional cyclic nucleotide-gated cation channel directly involved in the pathogen induced $\mathrm{Ca}^{2+}$ influx (CNGC2) activated during hypersensitive responses [64]. Interestingly, a high $\mathrm{Ca}^{2+}$ concentration in the fruit is an important pre-harvest parameter for the reduction of superficial

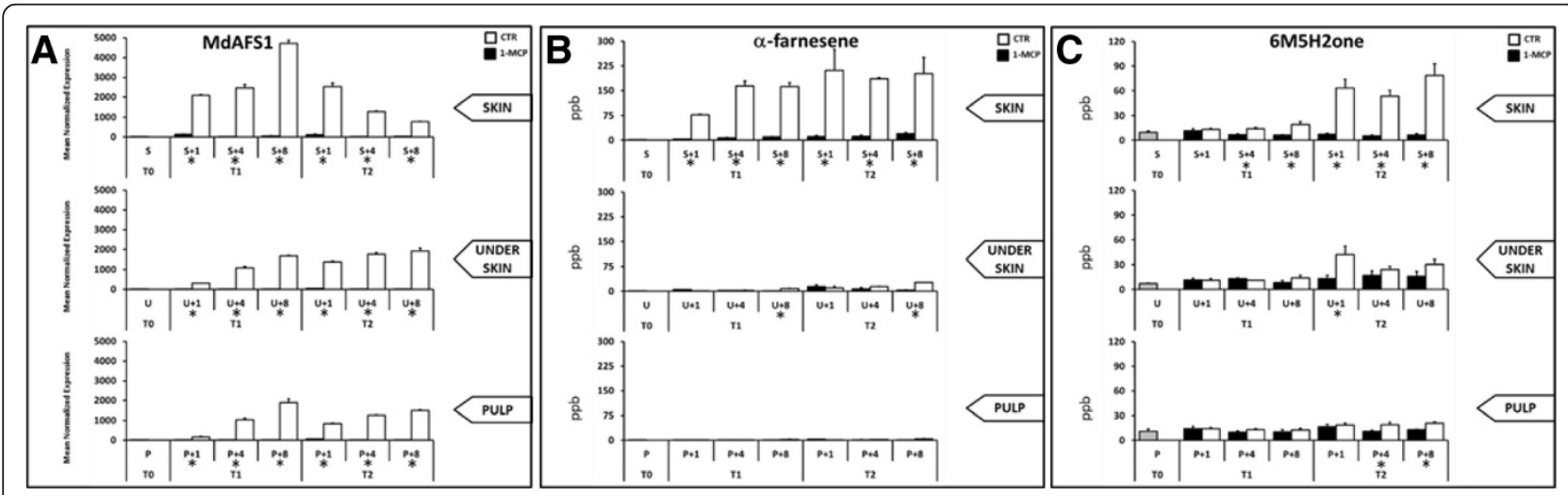

Figure 4 MdAFS1 expression analysis together with a-farnesene and 6M5H2one profiling using PTR-ToF-MS. The expression profile of MdAFS1, the gene responsible for a-farnesene biosynthesis, is shown in panel $\mathbf{A}$, while assessment of the metabolites concentration (in ppb) of a-farnesene and $6 \mathrm{M} 5 \mathrm{H} 2 \mathrm{one}$ is shown in panel $\mathbf{B}$ and $\mathbf{C}$, respectively. Asterisk indicates a difference statistically significant based on a LSD-ANOVA ( $P$-value $\leq 0.05)$. 
scald incidence $[87,88]$, as well as an ubiquitous signal in abiotic stress resistance, such as cold tolerance [89], and PCD [84,90]. Finally, AtLSD1 (AT4G20380) encodes a $\mathrm{C}_{2} \mathrm{H}_{2}$ zinc finger transcription factor that monitors a superoxide-dependent signal, which negatively regulates PCD in plants [65]. This gene indeed represents an intriguing connection between ROS-associated signalling, low temperature-dependent $\mathrm{PCD}$ and cold stress tolerance [91], and it is thought to limit cell death via up-regulation of $\mathrm{Cu}-\mathrm{Zn}$-superoxide dismutase acting as protection against uncontrolled oxidative processes during chilling injuries [92].
From the transcriptomic profiles of the three apple orthologs (Figure 5A, B and C), it is evident that starting from the re-establishment of room temperature, and only after two months of cold storage, the mRNA accumulation in the skin was lower as compared to the underskin and fruit pulp. This regulation was not observed in T1 stages, suggesting this difference was properly regulated by the occurrence of superficial scald disorder. The high gene expression in the two tissues not affected by the brown coloration, as compared to the skin, was also magnified by treatment with 1-MCP (Figure 5D), suggesting the involvement of an anti-apoptotic mechanism as a
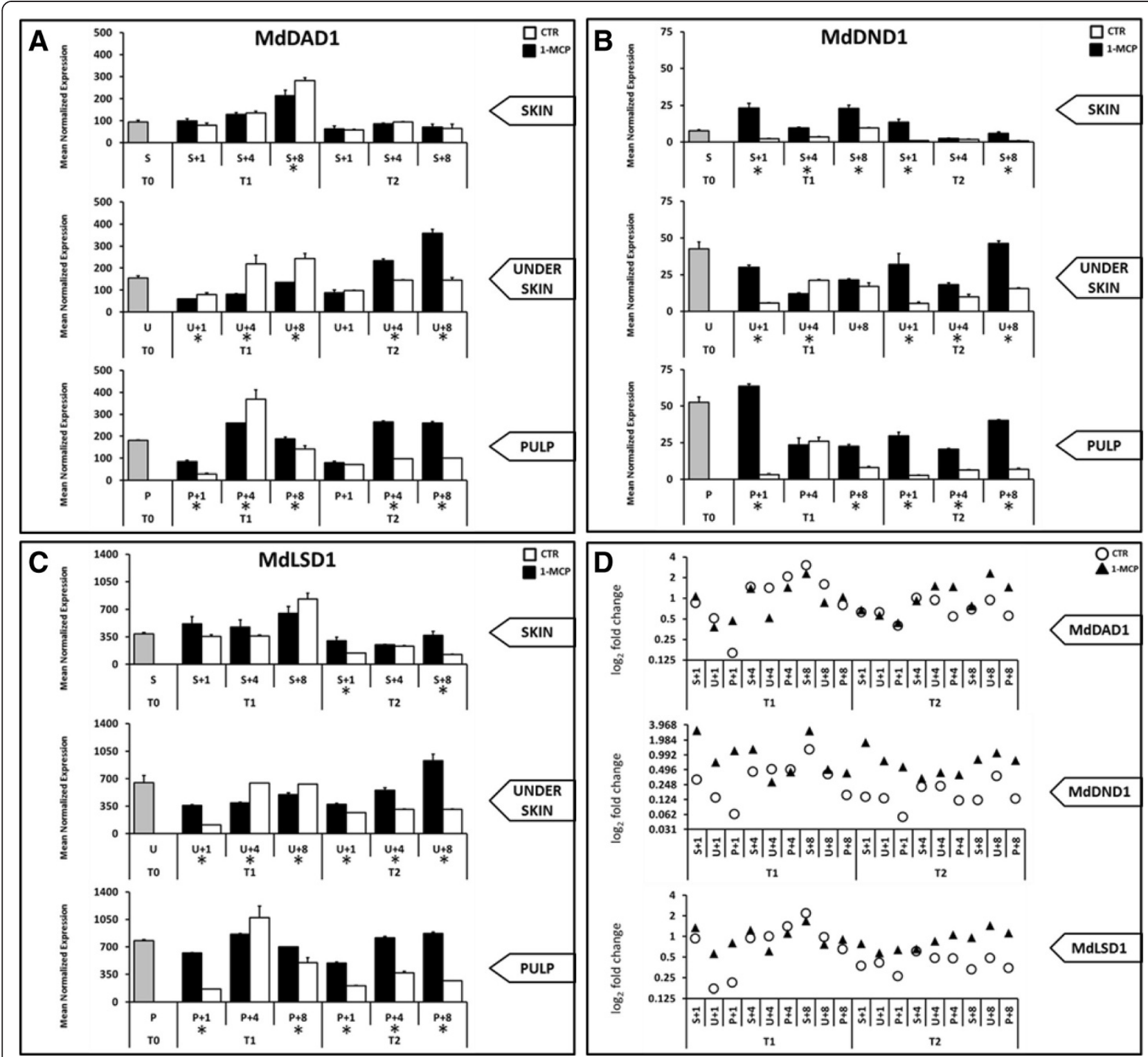

Figure 5 Expression profile of the three genes involved in the anti-apoptotic mechanism. Mean normalized expression of MdDAD1 (panel A), MdDND1 (panel B) and MdLSD1 (panel C) in the three apple tissues over time and comparison between the control (CTR) and treated (1-MCP) samples. The standard error is also reported for each bar. Panel " $\mathbf{D}$ " is instead shows the $\log _{2}$ fold change of the expression profile of these three genes anchored to the respective T0 stage. Asterisk indicates a difference statistically significant based on a LSD-ANOVA $(P$-value $\leq 0.05)$. 
protective system against scald. The anti-apoptotic system may thus act in connection with the oxidation of the chlorogenic acid as a self-defence mechanism. Following the signal released by the oxidation of $\alpha$-farnesene and the high accumulation of polyphenolic compounds, further protection of the underlying tissue may be initiated by the activation of these genes, which only contribute towards isolating scald progression in the skin of apple. It is interesting to note that a similar mechanism was observed in walnut transgenic line [93]. The silencing of $P P O$ leads to an over-accumulation of tyramine and polyphenolic substrate, with a corresponding decrease in their reaction products, underlying the possible connection between $P P O$ activity, polyphenols metabolism and PCD events.

\section{Conclusion}

The results described in this work shed light on the physiological process leading to scald development in apple, a harmful postharvest disorder affecting the marketability of specific apple cultivars. The analysis performed on the main polyphenolic cascade highlighted the pathway of chlorogenic acid, and its subsequent oxidation by polyphenoloxidase, as the major factor responsible for scald symptoms. In addition to this, we propose a new role for $\alpha$-farnesene and its oxidative product (CTols), as a triggering signal for browning. Finally, we also surmise the involvement of an anti-apoptotic regulation in order to prevent the diffusion of this disorder in the inner tissues of apple.

\section{Additional files}

Additional file 1: Figure S1. Experimental design. After harvest (TO), the apples were divided into two batches. The first was considered as a control (CTR), while the second was treated with 1-methyl-cyclo-propene $(1-\mathrm{MCP})$. Both subsets were placed in a cold storage room $\left(+0.5^{\circ} \mathrm{C}\right)$ for one and two months respectively. After cold storage, the treated and untreated fruit were placed at room temperature and sampled after one $(+1)$, four $(+4)$ and eight $(+8)$ days. 7 stages were thus defined (TO: harvest, $T 1_{+1}: 1$ month of cold storage +1 day of shelf life, $T 1_{+4}: 1$ month of cold storage +4 days of shelf life, $\mathrm{T1}_{+8}: 1$ month of cold storage +8 days of shelf life, $T 2_{+1}: 2$ months of cold storage +1 day of shelf life, $T 2_{+4}: 2$ months of cold storage +4 days of shelf life, $\mathrm{T}_{+}+2$ months of cold storage +8 days of shelf life). Moreover, each stage was repeated in three different tissues: S: skin, U: underskin and P: pulp.

Additional file 2: Figure S2. Sequence alignment of DND1, DAD1 and LSD1. Sequence alignment between the Arabidopsis protein sequences of DND1, DAD1 and LSD1 with their putative apple orthologs. The conserved residues are shown with black frames.

Additional file 3: Figure S3. Superficial scald development in "Granny Smith" apples. Representative pictures of superficial scald evolution in the control (CTR) and treated samples (1-MCP), after one (panel from A to F) and two months (panel from $\mathrm{G}$ to N) cold storage. Panel O shows a portion of scalded peeled apple tissue, at the T2 +8 stage, highlighting isolation of the brown coloration in the skin alone.

Additional file 4: Table S1. List of primers. List of all the primer pairs used in this work. The gene name, the annotation, the gene ID according to the code used in the apple genome database (www.rosaceae.org), the chromosome on which the gene is located, primer sequences designed for qRT-PCR analysis and the relative references are indicated for each pair.

Additional file 5: Figure S4. Polyphenolic compounds characterization. Characterization of four major classes of polyphenolic compounds, namely phlorizin, flavonols, catechin and epicatechin. The last panel instead shows the general phenolic accumulation profile, including all the categories investigated in this study. The amount of each compound is expressed as $\mu \mathrm{g} / \mathrm{g}$ of fresh weight (FW). The standard error is also reported for each bar. Asterisk indicates a difference statistically significant based on a LSD-ANOVA ( $P$-value $\leq 0.05)$.

Additional file 6: Table S2. Table of polyphenol compounds quantified in this work. The amount of each compound is expressed as $\mu \mathrm{g} / \mathrm{g}$ of fresh weight (FW). Each sample was represented by three separated biological replicates.

Additional file 7: Figure S5. Expression profile of genes involved in polyphenolic biosynthesis. Expression profile of all other genes participating in polyphenolic biosynthesis and not presented in the main text, namely MdCHS, MdCHI, MdF3H, MdDFR, MdANS, MdFLS, MdLAR and MdANR. The standard error is also reported for each bar. Asterisk indicates a difference statistically significant based on a LSD-ANOVA ( $P$-value $\leq 0.05$ ).

\section{Abbreviations}

PAL: Phenylalanine ammonia lyase; CHS: Chalcone synthase; CHI: Chalcone isomerase; MdF3H: Flavone 3-hydroxylase; DFR: Dihydroflavonol 4-reductase; ANS: Anthocyanidin synthase; C3H: p-coumarate 3-hydroxylase; FLS: Flavonol synthase; LAR: Leucoanthocyandin reductase; ANR: Anthocyanidin reductase; PPO: Polyphenol oxidase; AFS1: a-farnesene synthase; DAD1: Defender against cell death 1; DND1: Defense no death 1; LSD1: Lesion simulating disease resistance 1; 1-MCP: 1-methyl-cyclopropene; CTols: Conjugated trienols; 6M5H2one: 6-methyl-5-hepten-2-one; PCD: Programmed cell death, Md, Malus domestica; At: Arabidopsis thaliana.

\section{Competing interest}

The authors declare that they have no competing interest.

\section{Authors' contributions}

NB performed gene expression analysis and drafted the manuscript, AT supported the molecular work, BF performed metabolite and VOC analysis and contributed towards drafting the manuscript, UV interpreted the metabolite data, LC and FB interpreted the PTR-ToF-MS data, RV and GC supported the project, FC designed the experiment, coordinated the work and finished the manuscript. All authors read and approved the final manuscript.

\section{Acknowledgements}

The authors thank Barbara Novak for sample collection in the field. This research was founded by the Agroalimentare research AGER project (grant no. 2010-2119).

\section{Author details}

'Department of Agricultural Sciences, Bologna University, Via Fanin 46, 40127 Bologna, Italy. ${ }^{2}$ Research and Innovation Centre, Fondazione Edmund Mach, Via Mach 1, 38010 San Michele all'Adige, Trento, Italy.

Received: 12 June 2014 Accepted: 14 July 2014

Published: 20 July 2014

\section{References}

1. Giovannoni JJ: Molecular biology of fruit maturation and ripening. Annu Rev Plant Physiol Plant Mol Biol 2001, 52:725-749.

2. Klee HJ, Giovannoni JJ: Genetics and control of tomato fruit ripening and quality attributes. Annu Rev Genet 2011, 45:41-59.

3. Liu RH: Health-promoting components of fruits and vegetables in the diet. Adv Nutri 2013, 4:384S-392S.

4. Alexander L, Grierson D: Ethylene biosynthesis and action in tomato: a model for climacteric fruit ripening. J Exp Bot 2002, 53:2039-2055.

5. Bleecker $A B$, Kende $H$ : Ethylene: a gaseous signal molecule in plants. Ann Rev Cell Dev Biol 2000, 16:1-18. 
6. Johnston JW, Hewett EW, Hertog MLATM: Postharvest softening of apple (Malus domestica) fruit: a review. N Z J Crop Hortic Sci 2002, 30:145-160.

7. Lurie $\mathrm{S}$, Crisosto $\mathrm{CH}$ : Chilling injury in peach and nectarine. Postharvest Biol Technol 2005, 37:195-208.

8. Bouzayen M, Latché A, Nath P, Pech J: Plant Developmental Biology Biotechnological Perspectives. In Plant Developmental Biology Biotechnological Perspectives, Volume 1. Edited by Pua EC, Davey MR. Berlin, Heidelberg: Springer Berlin Heidelberg; 2010.

9. Wang SY, Faust M: Ethylene biosynthesis and polyamine accumulation in apples with watercore. J Ame Horticult Sci 1992, 117:133-138.

10. Larrigaudière $C$, Pintò $E$, Lentheric $L$, Vendrell M: Involvement of oxidative processes in the development of core browning in controlled-atmosphere stored pears. J Horticult Sci Biotechnol 2001, 76:157-162.

11. Franck C, Lammertyn J, Ho QT, Verboven P, Verlinden B, Nicolaï BM: Browning disorders in pear fruit. Postharvest Biol Technol 2007, 43:1-13.

12. Sevillano L, Sanchez-Ballesta MT, Romojaro F, Flores FB: Physiological, hormonal and molecular mechanisms regulating chilling injury in horticultural species: postharvest technologies applied to reduce its impact. J Sci Food Agric 2009, 89:555-573.

13. Pesis E, Ibáñez AM, Phu ML, Mitcham EJ, Ebeler SE, Dandekar AM: Superficial scald and bitter pit development in cold-stored transgenic apples suppressed for ethylene biosynthesis. J Agric Food Chem 2009, 57:2786-2792.

14. Rudell DR, Buchanan DA, Leisso RS, Whitaker BD, Mattheis JP, Zhu Y, Varanasi V: Ripening, storage temperature, ethylene action, and oxidative stress alter apple peel phytosterol metabolism. Phytochemistry 2011, 72:1328-1340.

15. Bain J, Mercer F: The Submicroscopic cytology of superficial scald, a physiological disease of apples. Aust J Biol Sci 1963, 16:442-449.

16. Watkins C, Bramlage WJ, Cregoe BA: Superficial scald of Granny Smith apples is expressed as a typical chilling injury. J Am Soc Horticult Sci 1995, 120:88-94.

17. Little CR, Holmes RJ: Storage technology for apples and pears: a guide to production, postharvest treatment and storage of pome fruit in Australia. Knoxfield, Australia: Horticultural Research \& Development Corporation; 2000.

18. Whitaker BD, Solomos T, Harrison DJ: Quantification of a-farnesene and its conjugated trienol oxidation products from apple peel by C18 -HPLC with UV detection. J Agric Food Chem 1997, 45:760-765.

19. Tsantili E, Gapper NE, Arquiza JMRA, Whitaker BD, Watkins CB: Ethylene and alpha-farnesene metabolism in green and red skin of three apple cultivars in response to 1-methylcyclopropene (1-MCP) treatment. J Agric Food Chem 2007, 55:5267-5276.

20. Lurie S, Watkins CB: Superficial scald, its etiology and control. Postharvest Biol Technol 2012, 65:44-60.

21. Rupasinghe HPV, Paliyath G, Murr DP: Biosynthesis of a-farnesene and its relation to superficial scald development in 'Delicious' apples. J Am Horticult Sci 1998, 123:882-886

22. Whitaker BD, Nock JF, Watkins CB: Peel tissue a -farnesene and conjugated trienol concentrations during storage of "White Angel" $x$ "Rome Beauty" hybrid apple selections susceptible and resistant to superficial scald. Postharvest Biol Technol 2000, 20:231-241.

23. Rowan DD, Hunt MB, Fielder S, Norris J, Sherburn MS: Conjugated triene oxidation products of alpha-farnesene induce symptoms of superficial scald on stored apples. J Agric Food Chem 2001, 49:2780-2787.

24. Arquiza AJMR, Hay AG, Nock JF, Watkins CB: 1-Methylcyclopropene interactions with diphenylamine on diphenylamine degradation, alpha-farnesene and conjugated trienol concentrations, and polyphenol oxidase and peroxidase activities in apple fruit. J Agric Food Chem 2005, 53:7565-7570.

25. Serek M, Tamari G, Sisler EC, Borochov A: Inhibition of ethylene-induced cellular senescence symptoms by 1-methylcyclopropene, a new inhibitor of ethylene action. Physiol Plant 1995, 94:229-232.

26. Costa F, Alba R, Schouten H, Soglio V, Gianfranceschi L, Serra S, Musacchi S, Sansavini S, Costa G, Fei ZJ, Giovannoni J: Use of homologous and heterologous gene expression profiling tools to characterize transcription dynamics during apple fruit maturation and ripening. $B M C$ Plant Biol 2010, 10:229.

27. Willis RBH, Ku WW: Use of 1-MCP to extend the time to ripen of green tomatoes and postharvest life of ripen tomatoes. Postharvest Biol Technol 2002, 26:85-90.
28. Guillen F, Castillo S, Zapata PJ, Martinez-Romero D, Serrano M, Valero D: Efficacy of 1-MCP treatment in tomato fruit 1: duration and concentration of 1-MCP treatment to gain an effective delay of postharvest ripening. Postharvest Biol Technol 2007, 43:23-27.

29. Tassoni A, Watkins CB, Davies PJ: Inhibition of the ethylene response by $1-\mathrm{MCP}$ in tomato suggests that polyamines are not involved in delaying ripening, but may moderate the rate of ripening or over-ripening. $J$ Exp Bot 2006, 12:3313-3325.

30. Dal Cin V, Rizzini FM, Botton A, Tonutti P: The ethylene biosynthetic and signal transduction pathways are differently affected by 1-MCP in apple and peach fruit. Postharvest Biol Technol 2006, 42:125-133.

31. Ziliotto F, Begheldo M, Rasori A, Bonghi C, Tonutti P: Transcriptome profiling of ripening nectarine (Prunus persica L. Batsch) fruit treated with 1-MCP. J Exp Bot 2008, 59:2781-2791.

32. Jung SK, Watkins CB: Superficial scald control after delayed treatment of apple fruit with diphenylamine (DPA) and 1-methylcyclopropene (1-MCP). Postharvest Biol Technol 2008, 50:45-52.

33. Lurie $S$, Lers A, Shacham Z, Sonego L, Burd S: Expression of a -farnesene synthase AFS1 and 3-Hydroxy-3-methylglutaryl-coenzyme A reductase HMG2 and HMG3 in relation to a -farnesene and conjugated trienols in Granny Smith ' apples heat or 1-MCP treated to prevent superficial scald. J Am Horticult Sci 2005, 130:232-236.

34. Pechous SV, Whitaker BD: Cloning and functional expression of an $(\mathrm{E}, \mathrm{E})$-a-farnesene synthase cDNA from peel tissue of apple fruit. Planta 2004, 219:84-94.

35. Gapper NE, Bai J, Whitaker BD: Inhibition of ethylene-induced a-farnesene synthase PCAFS1 expression in 'd'Anjou' pears with 1-MCP reduces synthesis and oxidation of a-farnesene and delays development of superficial scald. Postharvest Biol Technol 2006, 41:225-233.

36. Pesis E, Feygenberg O, Goldenberg L, Sabban-Amin R: Superficial scald symptoms in 'Granny Smith' apples associated with reactive oxygen species (ROS) accumulation. Proc Fla State Horticult Soc 2012, 125:276-279.

37. Nicolas JJ, Richard-Forget FC, Goupy PM, Amiot MJ, Aubert SY: Enzymatic browning reactions in apple and apple products. Crit Rev Food Sci Nutr 1994, 34:109-157.

38. Valentines MC, Vilaplana R, Torres R, Usall J, Larrigaudière C: Specific roles of enzymatic browning and lignification in apple disease resistance. Postharvest Biol Technol 2005, 36:227-234.

39. Mao L, Lu F, Wang G: Application of 1-methylcyclopropene reduces wound responses and maintains quality in fresh-cut apple. Asia PaC J Clin Nutr 2007, 16(Suppl 1):111-115.

40. Di Guardo M, Tadiello A, Farneti B, Lorenz G, Masuero D, Vrhovsek U, Costa G, Velasco R, Costa F: A multidisciplinary approach providing new insight into fruit flesh browning physiology in apple (Malus $x$ domestica Borkh). Plos One 2013, 8. doi:10.1371/journal.pone.0078004.

41. Boss PK, Gardner RC, Janssen BJ, Ross GS: An apple polyphenol oxidase cDNA is up-regulated in wounded tissues. Plant Mol Biol 1995, 27:429-433

42. Piretti M, Gallerani G, Brodnik U: Polyphenol polymerisation involvement in apple superficial scald. Postharvest Biol Technol 1996, 8:11-18.

43. Brooks C, Cooley J, Fisher D: Nature and control of apple scald. J Agric Res 1919, XVIII:211-241.

44. Tiller $L$ : Cold storage of fruit: investigations conducted with apples during 1927 and 1928. N Z Dep Sci Ind Res 1929, 16:23.

45. Jemrić T, llić Z: Present state of cold chain and postharvest loss of fruits and vegetables in Croatia and Serbia. Agric Conspec Sci 2012, 77:1-4

46. Blankenship S, Dole J: 1-Methylcyclopropene: a review. Postharvest Biol Technol 2003, 28:1-25.

47. Smock R: A comparison of treatments for control of the apple scald disease. Am Soc Horticult Sci 1957, 69:91-100.

48. Watkins CB: The use of 1-methylcyclopropene (1-MCP) on fruits and vegetables. Biotechnol Adv 2006, 24:389-409.

49. Gapper NE, McQuinn RP, Giovannoni JJ: Molecular and genetic regulation of fruit ripening. Plant Mol Biol 2013, 82:575-591.

50. Ziosi V, Noferini M, Fiori G, Tadiello A, Trainotti L, Casadoro G, Costa G: A new index based on vis spectroscopy to characterize the progression of ripening in peach fruit. Postharvest Biol Technol 2008, 49:319-329.

51. Nyasordzi J, Friedman $H$, Schmilovitch $Z$, Ignat $T$, Weksler A, Rot Lurie S: Utilizing the IAD index to determine internal quality attributes of apples at harvest and after storage. Postharvest Biol Technol 2013, 77:80-86. 
52. Livak KJ, Schmittgen TD: Analysis of relative gene expression data using real-time quantitative PCR and the 2(-Delta Delta C(T)) Method. Methods 2001, 25:402-408.

53. Longhi S, Moretto M, Viola R, Velasco R, Costa F: Comprehensive QTL mapping survey dissects the complex fruit texture physiology in apple (Malus x domestica Borkh. J Exp Bot 2012, 63:1107-1121.

54. Botton A, Eccher G, Forcato C, Ferrarini A, Begheldo M, Zermiani M, Moscatello S, Battistelli A, Velasco R, Ruperti B, Ramina A: Signaling pathways mediating the induction of apple fruitlet abscission. Plant Physiol 2011, 155:185-208.

55. Henry-Kirk RA, McGhie TK, Andre CM, Hellens RP, Allan AC: Transcriptional analysis of apple fruit proanthocyanidin biosynthesis. J Exp Bot 2012 63:5437-5450

56. Kim S, Lee J, Hong S, Yoo Y, An G, Kim S: Molecular cloning and analysis of anthocyanin biosynthesis genes preferentially expressed in apple skin. Plant Sci 2003, 165:403-413.

57. Espley RV, Hellens RP, Putterill J, Stevenson DE, Kutty-Amma S, Allan AC: Red colouration in apple fruit is due to the activity of the MYB transcription factor, MdMYB10. Plant J 2007, 49:414-427.

58. Li H, Flachowsky H, Fischer TC, Hanke M-V, Forkmann G, Treutter D, Schwab W, Hoffmann T, Szankowski l: Maize Lc transcription factor enhances biosynthesis of anthocyanins, distinct proanthocyanidins and phenylpropanoids in apple (Malus domestica Borkh). Planta 2007, 226:1243-1254.

59. Han Y, Vimolmangkang S, Soria-Guerra RE, Rosales-Mendoza S, Zheng D, Lygin AV, Korban SS: Ectopic expression of apple F3' H genes contributes to anthocyanin accumulation in the Arabidopsis tt7 mutant grown under nitrogen stress. Plant Physiol 2010, 153:806-820.

60. Han Y, Vimolmangkang S, Soria-Guerra RE, Korban SS: Introduction of apple ANR genes into tobacco inhibits expression of both $\mathrm{CHI}$ and DFR genes in flowers, leading to loss of anthocyanin. J Exp Bot 2012, 63:2437-2347.

61. Telias A, Lin-Wang K, Stevenson DE, Cooney JM, Hellens RP, Allan AC, Hoover EE, Braaden JM: Apple skin patterning is associated with differential expression of MYB10. BMC Plant Biol 2011, 11:93.

62. Harb J, Saleh O, Kittemann D, Neuwald DA, Frank W, Reski R: Upregulation of polyphenol-related genes prevents "skin burning" of well-colored "Cameo" apples stored under stressful controlled atmosphere conditions. Postharvest Biol Technol 2013, 77:121-127.

63. Dong YH, Zhan XC, Kvarnheden A, Atkinson RG, Morris BA, Gardner RC: Expression of a cDNA from apple encoding a homologue of DAD1, an inhibitor of programmed cell death. Plant Sci 1998, 139:165-174.

64. Clough SJ, Fengler KA, Yu IC, Lippok B, Smith RK, Benta F: The Arabidopsis dnd1 "defense, no death" gene encodes a mutated cyclic nucleotide-gated ion channel. Proc Natl Acad Sci U S A 2000, 97:9323-9328.

65. Dietrich RA, Richberg MH, Schmidt R, Dean C, Dangl JL: A novel zinc finger protein is encoded by the Arabidopsis LSD1 gene and functions as a negative regulator of plant cell death. Cell 1997, 88:685-694.

66. Theodoridis G, Gika H, Franceschi P, Caputi L, Arapitsas P, Scholz M, Masuero D, Wehrens R, Vrhovsek U, Mattivi F: LC-MS based global metabolite profiling of grapes: solvent extraction protocol optimization. Metabolomics 2012, 8:175-185.

67. Vrhovsek U, Masuero D, Gasperotti M, Franceschi P, Caputi L, Viola R, Mattivi F: A versatile targeted metabolomics method for the rapid quantification of multiple classes of phenolics in fruits and beverages. J Agric Food Chem 2012, 60:8831-8840.

68. Cappellin L, Biasioli F, Schuhfried E, Soukoulis C, Märk TD, Gasperi F: Extending the dynamic range of proton transfer reaction time-of-flight mass spectrometers by a novel dead time correction. Rapid Commun Mass Spectrom 2011, 25:179-183.

69. Cappellin L, Biasioli F, Granitto PM, Schuhfried E, Soukoulis C, Costa F, Märk TD, Gasperi F: On data analysis in PTR-TOF-MS: from raw spectra to data mining. Sens Actuators B Chem 2011, 155:183-190

70. Lindinger W, Hansel A, Jordan A: On-line monitoring of volatile organic compounds at pptv levels by means of proton- transfer-reaction mass spectrometry (PTR-MS) - medical appli- cations, food control and environmental research. Int J Mass Spectrom Ion Phys 1998, 173:191-241.

71. Cappellin L, Karl T, Probst M, Ismailova O, Winkler PM, Soukoulis C, Aprea E, Märk TD, Gasperi F, Biasioli F: On quantitative determination of volatile organic compound concentrations using proton transfer reaction time-of-flight mass spectrometry. Env Sci Technol 2012, 46:2283-2290.

72. Yang $X$, Song J, Campbell-Palmer L, Fillmore S, Zhang Z: Effect of ethylene and 1-MCP on expression of genes involved in ethylene biosynthesis and perception during ripening of apple fruit. Postharvest Biol Technol 2013, 78:55-66.

73. Sabban-Amin R, Feygenberg O, Belausov E, Pesis E: Low oxygen and 1-MCP pretreatments delay superficial scald development by reducing reactive oxygen species (ROS) accumulation in stored "Granny Smith" apples. Postharvest Biol Technol 2011, 62:295-304.

74. Golding JB, McGlasson WB, Wyllie SG, Leach DN: Fate of apple peel phenolics during cool storage. J Agric Food Chem 2001, 49:2283-2289.

75. Vrhovsek U, Rigo A, Tonon D, Mattivi F: Quantitation of polyphenols in different apple varieties. J Agric Food Chem 2004, 52:6532-6538.

76. Łata B, Trampczynska A, Paczesna J: Cultivar variation in apple peel and whole fruit phenolic composition. Sci Hortic 2009, 121:176-181.

77. Rao MV, Watkins CB, Brown SK, Weeden NF: Active oxygen species metabolism in White Angel' $\times$ Rome Beauty' apple selections resistant and susceptible to superficial scald. J Am Soc Horticult Sci 1998, 123:299-304.

78. Marangoni AG, Palma T, Stanley DW: Membrane effects in postharvest physiology. Postharvest Biol Technol 1996, 7:193-217.

79. Zhou Y, Pan X, Qu H, Underhill S: Low temperature alters plasma membrane lipid composition and ATPase activity of pineapple fruit during blackheart development. J Bioenerg Biomembr 2014, 46:59-69.

80. Rupasinghe HPV, Almquist KC, Paliyath G, Murr DP: Hmg1 and hmg2 cDNAs encoding 3-hydroxy-3-methylglutaryl coenzyme A reductase and their expression and activity in relation to a-farnesene synthesis in apple. Plant Physiol Biochem 2001, 39:933-947.

81. Rudell DR, Mattheis JP, Fellman JK: Relationship of superficial scald development and alpha-farnesene oxidation to reactions of diphenylamine and diphenylamine derivatives in Cv. Granny Smith apple peel. J Agric Food Chem 2005, 53:8382-8389.

82. Soukoulis C, Cappellin L, Aprea E, Costa F, Viola R, Märk TD, Gasperi F, Biasioli F: PTR-ToF-MS, a novel, rapid, high sensitivity and non-invasive tool to monitor volatile compound release during fruit post-harvest storage: the case study of apple ripening. Food Bioprocess Technol 2013, 6:2831-2843.

83. Whitaker BD, Saftner RA: Temperature-dependent autoxidation of conjugated trienols from apple peel yields 6-methyl-5-hepten-2-one, a volatile implicated in induction of scald. J Agric Food Chem 2000, 48:2040-2043

84. Woltering E, lakimova E: Programmed cell death and postharvest deterioration of horticultural produce. Acta Horticult 2010, 877:991-998.

85. Wang C, Bowen J, Weir I, Allan AC, Ferguson IB: Heat-induced protection against death of suspension cultured apple fruit cells exposed to low temperature. Plant Cell Environ 2001, 24:1199-1207.

86. $\mathrm{Xu} C$, Chen $\mathrm{K}$, Ferguson IB: Programmed cell death features in apple suspension cells under low oxygen culture. J Zhejiang Univ (Sci) 2004, 5:137-143.

87. Emongor VE, Murr DP, Lougheed EC: Preharvest factors that predispose apples to superficial scald. Postharvest Biol Technol 1994, 4:289-300.

88. Fadhil NN: Relationship between fruit content of N, Ca and Mg and physiological disorders of apples cvs. Fuji and Granny Smith. Afr Crop Sci Conf Proc 2007, 8:407-409.

89. Thomashow MF: Plant cold acclimation: freezing tolerance genes and regulatory mechanisms. Annu Rev Plant Physiol Plant Mol Biol 1999, 50:571-599.

90. Hoeberichts FA, Woltering EJ: Multiple mediators of plant programmed cell death: interplay of conserved cell death mechanisms and plant-specific regulators. BioEssays 2003, 25:47-57.

91. Huang X, Li Y, Zhang X, Zuo J, Yang S: The arabidopsis LSD1 gene plays an important role in the regulation of low temperature-dependent cell death. New Phytol 2010, 187:301-312.

92. Kliebenstein DJ, Dietrich RA, Martin AC, Last RL, Dangl JL: LSD1 regulates salicylic acid induction of copper zinc superoxide dismutase in Arabidopsis thaliana. Mol Plant-Microbe Interact 1999, 12:1022-1026.

93. Araji S, Grammer TA, Gertzen R, Anderson SD, Mikulic-Petkovsek M, Veberic R, Phu ML, Solar A, Leslie CA, Dandekar AM, Escobar MA: Novel roles for the polyphenol oxydase enzyme in secondary metabolism and the regulation of cell death in walnut. Plant Physiol 2014, 164:1191-1203.

doi:10.1186/s12870-014-0193-7

Cite this article as: Busatto et al:: Target metabolite and gene transcription profiling during the development of superficial scald in apple (Malus x domestica Borkh). BMC Plant Biology 2014 14:193. 